bioRxiv preprint doi: https://doi.org/10.1101/2021.12.13.472353; this version posted December 13, 2021. The copyright holder for this preprint (which was not certified by peer review) is the author/funder, who has granted bioRxiv a license to display the preprint in perpetuity. It is made available under aCC-BY 4.0 International license.

\title{
Seasonal resistome diversity and dissemination of WHO priority antibiotic-resistant pathogens in Lebanese estuaries
}

Wadad Hobeika ${ }^{1,2}$, Margaux Gaschet ${ }^{1}$, Marie-Cécile Ploy ${ }^{1}$, Elena Buelow ${ }^{3 *}$, Dolla Karam Sarkis ${ }^{2 *}$, Christophe Dagot ${ }^{1 *}$

1 Université de Limoges, INSERM, CHU Limoges, UMR 1092, Limoges, France; marie-cecile.ploy@unilim.fr

2 Microbiology laboratory, School of Pharmacy, Saint-Joseph University, Beirut, Lebanon; dolla.sarkis@usj.edu.lb

3 Université Grenoble Alpes, CNRS, TIMC-IMAG, 38000 Grenoble; elena.buelow@gmail.com

* Authors contributed equally

Corresponding author: elena.buelow@gmail.com; christophe.dagot@unilim.fr

Abstract: Anthropogenic activities are demonstrated to be the key drivers of antimicrobial resistance (AMR) dissemination in the environment. Lebanese rivers that lead to the Mediterranean Sea were sampled at estuaries' sites, under high anthropogenic pressure, in spring 2017 and winter 2018 to study seasonal variation of antimicrobial-resistant bacteria (ARBs) and antimicrobial resistance genes (ARGs). Methods: A combined approach using culture techniques and high throughput qPCR identified hotspots for antimicrobial resistance and anthropogenic pressure in particular locations along the Lebanese coast. Results: Multi-resistant Gram-negative (Enterobacterales and Pseudomonas spp) and Gram-positive bacterial pathogens were isolated. A high abundance of certain ARGs (vanB, bla $a_{\mathrm{BIC}-1, \text { bla }}$ GEs, tetM, and $\left.m c r-1\right)$ was detected in 5 Lebanese estuaries. The relative abundance of ARGs was highest in winter and areas with high anthropogenic activities and population growth with an influx of refugees. Conclusion: Qualitative analysis of ARB and the analysis of the Lebanese estuaries' resistome revealed critical levels of contamination with pathogenic bacteria and provided significant information about the spread of ARGs in anthropogenically impacted estuaries.

\section{Introduction}

Antimicrobial resistance (AMR) is a One Health crisis aggravated by the lack of water and pollution management on a global scale ${ }^{1,2}$.Anthropogenic activities are demonstrated to be the key drivers of AMR dissemination in the environment ${ }^{3,4,5,6}$ subsequently altering its ecosystems ${ }^{7,8,9}$. Through discharge of treated or untreated wastewater (WW) effluents into surface water, a high abundance of antibiotic resistance genes (ARGs), antibiotic-resistant bacteria (ARBs), and mobile genetic elements (MGEs) mixed with a cocktail of micropollutants and drug residues are continuously disseminated into the environment ${ }^{10,11,12,13}$. Additionally, agricultural practices such as soil fertilization with manure and sludge, or irrigation with WW effluents, further expand the environmental background levels of pollutants associated with the dissemination of antimicrobial resistance ${ }^{14,9}$. In Lebanon, rules to control the overuse and misuse of antibiotics for treatment, growth promotion, and prophylaxis in agriculture and animal husbandry are not strictly implemented ${ }^{15,16}$ which would likely contribute to increasing AMR in the Lebanese and connected environments ${ }^{17,18}$.

The surveillance of AMR in the environment is often assessed through ARG quantification ${ }^{19,20}$. High abundances of ARGs were found to be associated with fecal contamination $21,22,23$. 
bioRxiv preprint doi: https://doi.org/10.1101/2021.1213.472353; this version posted December 13,2021 . The copyright holder for this preprint (which was not certified by peer review) is the author/funder, who has granted bioRxiv a license to display the preprint in perpetuity. It is made available under aCC-BY 4.0 International license.

Estuaries are transitional zones between rivers and sea bodies ${ }^{24,25}$ exhibiting properties of marine and freshwater and underlining continental-oceanic interactions ${ }^{26}$. Estuaries are also considered filtering and buffered ecosystems broadly anthropized ${ }^{24,27}$. Contaminants can reside for prolonged periods due to the tidal streams ${ }^{27,28}$. The spatial-temporal dissemination of ARB and ARGs in estuaries remains understudied ${ }^{26}$. The Mediterranean coastline is densely populated with a large anthropic footprint, i.e. intensive fishing, shipping, recreational and industrial activities ${ }^{29}$. Our study aims to identify the impact of anthropogenic activities in AMR dissemination in the Mediterranean Sea through the Lebanese estuaries. The objectives of this study were to monitor in the Lebanese river estuaries, the dissemination of i) ARBs, notably extendedspectrum $\beta$-lactamase-producing-Enterobacterales (ESBL-E), multi-drug resistant Pseudomonas aeruginosa, and methicillinresistant Staphylococcus aureus (MRSA), and ii) the resistome through the detection of ARGs and MGEs.

\section{Results}

\section{Bacterial culture}

In total, we isolated 19 different bacterial species in different quantities in spring and winter from the estuarine water samples along the Lebanon coastline (see the Materials and Methods section) (Table 1). From $1 \mathrm{~mL}$ of the water samples cultivated on selective media, we obtained 50 and 10064 CFUs (colony forming units) resistant Enterobacterales and 41 and 43 CFUs resistant Pseudomonas spp. in spring and winter respectively. However, among the 10064 CFUs in winter, $10^{4}$ corresponded to the same bacterial species (Hafnia alvei) in the Beirut estuary. A more diverse panel of Enterobacterales species was isolated in spring. Enterobacetrales and/or Pseudomonas spp. strains were isolated from all samples, except the Bared river. Moreover, Enterobacterales were not detected in the Kaleb river and Pseudomonas spp were not found in the Zahnari river. MRSA isolates were detected only in spring.

\section{Susceptibility profiles}

We performed susceptibility testing for a panel of Enterobacterales (33) and Pseudomonas (39) strains. The results are shown in Table 2. We found 16 out of the 33 Enterobacterales and 6 out of the 39 Pseudomonas strains tested that expressed an ESBL phenotype detected with the synergy test.

Resistance towards the tested antibiotics was broadly disseminated. All tested strains of Pseudomonas in spring were susceptible to gentamicin. In winter, we detected 2 Pseudomonas aeruginosa strains with an ESBL synergy test, 1 in Janoubi and 1 in Beirut. We detected 5 strains resistant to imipenem in spring, 3 ESBL positive Pseudomonas luteola strains (2 in Aarqa and 1 in Beirut), and 2 Enterobacterales strains (1 ESBL Klebsiella oxytoca in Aarqa and 1 Serratia marcescens in Qadicha). No resistant strains to imipenem were detected in winter.

\section{Resistome}

Total DNA was extracted from triplicate river samples collected at the 10 estuaries of the major Lebanese rivers. Figure 1 depicts the abundance of each targeted gene normalized to the 16S rRNA encoding gene. 
bioRxiv preprint doi: https://doi.org/10.1101/2021.12.13.472353; this version posted December 13, 2021. The copyright holder for this preprint (which was not certified by peer review) is the author/funder, who has granted bioRxiv a license to display the preprint in perpetuity. It is made available under aCC-BY 4.0 International license.

Overall, a higher normalized abundance of the targeted resistome was detected during winter, except for the Qadicha estuarine, in which high normalized abundance for ARGs was detected for all samples and seasons.

The IncP1 anthropogenic marker was detected in all samples at medium concentrations.

Interestingly, individual genes were detected in specific samples and sites to be highly abundant. For example, the highest normalized abundance in winter was detected for the $\mathrm{mcr}-1$ gene in the Zahrani river samples, followed by the tetB gene.

Noticeably, the bla $a_{\mathrm{BI}-1}$ and tet $M$ genes were found in high normalized abundance in the Ostuene and Kaleb samples respectively. Also, during spring, the $v a n B$ gene was abundant in the estuarine samples from Aarqa, and the ESBL bla GES gene was abundant in the Qadicha sample in spring.

The resistome signatures are different according to the season with a higher diversity in spring. A more conserved pattern is observed in winter, especially in the northern samples (Janoubi, Ostuene, Aarqa, and Bared). The resistome signatures from the middle section to the South of Lebanon, in addition to those from Qadicha, are more diverse.

The seasonal variation of the ARGs normalized abundance in the estuaries was assessed using the non-parametric Wilcoxon's test. Figure 3 shows the estuaries where a significant increase of the mean normalized abundance was observed between spring and winter. The $p$ values corresponding to all the significant variations are available in Supplementary Table 2.

Although we observed a significant increase for most of the estuaries, the mean normalized abundances of efflux pumps, tetracyclines, ß-lactams, heavy metal resistance genes in addition to the mobile genetic elements (MGEs) significantly decreased from spring to winter $(p<0.04)$ in the Qadicha and Damour estuaries. In Qadicha, the aminoglycoside and macrolide resistance genes decreased significantly $(p<0.04)$.

\section{Discussion}

Previous studies underlined the contamination of Lebanese rivers with fecal bac-teria especially Escherichia coli and coliforms, reaching $70.4 \%$ of the rivers in the North and $60 \%$ in the Bekaa region, which was over the acceptable threshold they used ${ }^{30}$.

Lebanon is located in the eastern Mediterranean area along a coastal length of $220 \mathrm{~km}^{29}$ and is characterized by a short, cold, and wet winter season from January to March with annual rainfall ranging between $850 \mathrm{~mm}$ and $1800 \mathrm{~mm} /$ year, and by a dry summer ${ }^{31,32}$. The surface waters in Lebanon are under increased pressure from anthropic activities, i.e. urban, industrial, and recreational. Agriculture in the coastal zone in Lebanon requires irrigation with surface and groundwater causing the depletion of water resources while increasing pollution according to the Food and Agriculture organization report of the year $2016{ }^{33}$.

In our study, we showed that the relative abundance of the resistome varied according to the location. Figure 4 marks anthropogenic impact on the different geographic locations of Lebanon by indicating important urban zones, industrial zones, and activity, as well as zones with high population densities due to the influx of refugees. The Lebanese coastal belt from Tripoli to Tyre is the urbanized zone also witnessing agricultural activities. The highest count of bacteria, (Enterobacterales (Hafnia alvei $\left(10^{4}\right)$ ) in winter and Pseudomonas luteola $\left(10^{4}\right)$ in spring) was observed in the estuary of the capital Beirut. The highest cumulated 
bioRxiv preprint doi: https://doi.org/10.1101/2021.12.13.472353; this version posted December 13, 2021. The copyright holder for this preprint (which was not certified by peer review) is the author/funder, who has granted bioRxiv a license to display the preprint in perpetuity. It is made available under aCC-BY 4.0 International license.

normalized abundance of ARGs was observed in the Qadicha estuary in spring which is consistent with a high industrial and urbanization influence in the area. The Qadicha river is a small river impacted by population growth, with industrial activities and a chronic default of wastewater treatment. It has been shown that the estuary of this river was highly contaminated with pollutants ${ }^{34}$. The highest diversity of Enterobacterales was obtained from the Aarqa estuary in spring while a higher bacterial count was observed in winter (Klebsiella pneumoniae 50 UFC). The Aarqa estuary is located on the northern rural coast, inhabited by local and refugee communities with high agricultural activities. The elevated normalized abundance detected for the mobile colistin resistance gene mcr-1 in the Zahrani estuary in winter could be linked to its closely located poultry production sites in Nabatyeh, where elevated numbers of $E$. coli carrying the $m c r-1$ gene were isolated ${ }^{35}$. The surface runoff from those broiler farms might impact and contaminate the Zahrani river with the $m c r-1$ gene. Colistin is a polymixin antibiotic serving as the last-resort drug for carbapenemase-producing Enterobacterales - associated infections ${ }^{36}$. The high abundance of the mcr-1 gene is cause for concern as horizontal transfer to pathogens may occur under anthropogenic pressure ${ }^{37}$.

We observed a high relative abundance of ARGs in the North (Figure 3) which corresponds to the area with a high density of refugees camps and with the highest number of inhabitants (Table 3). Lebanon hosts the largest number of refugees per capita worldwide. The Syrian crisis in the year 2011 has escalated the rivers' water pollution, particularly on the northern coast following the migratory inflow of displaced persons searching for water points and settling to find refuge while infrastructure is lacking ${ }^{33}$. This inflow has contributed to sustaining extreme hot spots of water stress in urban areas in informal settlements (the Northern coast or in the Bekaa region) while water networks and governance are already insufficient ${ }^{38}$. In addition to the efforts from humanitarian organizations such as the UNHCR and the UNICEF to improve the sanitary of a fraction of the displaced people by the implementation of water and wastewater facilities, local initiatives to strengthen and/or rehabilitate existing infrastructure also exist and have to be continued to alleviate the vulnerability of displaced communities and to reduce the water stress in the country ${ }^{39,40}$.

Generally, we could observe seasonal differences for the resistome and resistant bacterial isolates between spring and winter. River water levels in Lebanon increase during spring due to the rise of underground water and the snowmelt ${ }^{41}$. This seasonal difference in water levels may contribute to the observed lower normalized abundances of the resistome in spring compared to the winter season (Figure 1). However, when analyzing the resistome signature, we observed a higher diversity of ARGs in spring (Figure 2). This could be explained by the fact that with the rise of temperature, people play, bathe, and do picnics along the beach and in estuaries, hence the observed diversity for the resistome in spring may reflect an impact due to recreational activities.

Most bacteria that were isolated from the rivers were highly resistant to antibiotics, especially to ß-lactams, while $16 / 33$ Enterobacterales strains and 6/39 Pseudomonas strains expressed an ESBL phenotype. The resistome analysis showed a diversity of ESBL-encoding genes, including a high abundance of bla $a_{\mathrm{BC}-1}$ in the Ostuene river in North Lebanon. The bla $a_{\mathrm{BBC}-1}$ gene was first characterized in 2002 in an E. coli strain in Greece, another country of the Mediterranean area ${ }^{42}$. We also detected the ESBL gene bla $_{\text {PER-1 }}$ that was previously described in P. aeruginosa strains in other Middle East countries (Iran, Turkey, Tunisia) ${ }^{43,44,45}$, as well as the bla $a_{\mathrm{CTX}-\mathrm{M}}$ and bla $a_{\mathrm{GES}} \mathrm{ESBL}$ genes that are distributed worldwide in Enterobacterales and Pseudomonas strains. We also identified Enterobacterales and Pseudomonas strains resistant to imipenem. The resistome analysis led to the detection of a few $b^{\prime} a_{\mathrm{NDM}}$ and bla $\mathrm{OXA}_{\mathrm{A}}$ genes (including the carbapenemase OXA-48 encoding gene) in the rivers. Furthermore, it is known that some GES enzymes can also hydrolyze carbapenems ${ }^{46}$. Altogether, the presence of ESBL and carbapenemase-producing pathogens and 
bioRxiv preprint doi: https://doi.org/10.1101/2021.12.13.472353; this version posted December 13, 2021. The copyright holder for this preprint (which was not certified by peer review) is the author/funder, who has granted bioRxiv a license to display the preprint in perpetuity. It is made available under aCC-BY 4.0 International license.

corresponding ARGs in the Lebanon estuaries raise concerns for public health, as in case of infection with these resistant bacteria, physicians have to rely on drug combinations and last-resort antibiotics ${ }^{47}$.

Similar to our findings, multidrug-resistant Enterobacterales, namely Enterobacter cloacae, Escherichia coli, and Klebsiella pneumoniae, were isolated from the human-impacted Melayu river estuary in Malaysia with antibiotic resistance attaining $100 \%$ to antibiotics such as cefotaxime ${ }^{48}$. Inversely, resistant Enterobacterales in the urbanized San Francisco Bay were absent from the near-shore sediments suggesting that urbanized estuaries may not constitute a major human exposure hazard when secondary and tertiary treatment operations and control measures for all wastewaters that drain into the studied environment are implemented ${ }^{49}$.

The presence of MRSA in Aarqa, Ostuene, and Awali estuaries detected in spring should be closely monitored since studies have clearly shown that Staphylococcus aureus and MRSA persist in anthropized river samples presenting a potential source of the dissemination and transmission of resistant bacteria ${ }^{50,51,52}$.

Currently, wastewater treatment plants (WWTP) in Lebanon have reported to mainly use secondary systems, although their status of operationality is undetermined. Two facilities in the Bekaa using a tertiary treatment system and 4 (3 in Mount Lebanon and 1 in the South) use a primary treatment system ${ }^{33}$. The number of WWTP is proportional to the number of inhabitants, however, to prevent subsequent health effects from potential pathogens associated with poorly treated water ${ }^{53}$, the number of WWTP using advanced technologies such as the tertiary treatment system that combines activated sludge with methods of reducing the bacterial load (disinfection, ultrafiltration) is scarce and should be increased.

Here, we identified the estuaries of Lebanon as putative host-spots for the dissemination of ARGs and resistant bacteria into the Mediterranean Sea. Recreational waters as rivers and beaches have gained increased attention as having a central role in the persistence, dissemination, and emergence of antibiotic resistance ${ }^{54}$. Specific surveillance systems should be put in place that traces urban movements, contact with recreational waters, pollution levels, and WW treatment levels and management to trace the actual dissemination of antimicrobial resistance through recreational waters ${ }^{55}$.

\section{Materials and Methods}

Fifteen perennial Lebanese rivers spread through or at the extension of the Mount of Lebanon for a dozen of km eastward before discharging in small catchment areas leading to the Mediterranean Sea ${ }^{56}$. The rivers spread over the territory making it a dense network of watercourses at a less than $10 \mathrm{~km}$ distance from each other and sharing similar basin characteristics ${ }^{56}$. To evaluate the seasonal impact on the presence and abundance of ARBs and ARGs, sampling campaigns have been performed at two different periods.

Twelve estuaries or mouths were sampled in triplicate in sterile cups in April 2017 and January 2018 resulting in n=72 river water samples: 36 in spring and 36 in winter ( 3 samples of $60 \mathrm{ml}$ each taken one after the other per river) (Figure 5). Weather conditions in terms of temperature with slight or no precipitation were similar along with the month duration for each of the two sampling campaigns. Samples were transported on ice directly to our Lebanese laboratory for further analysis within 2 hours. The Jawz river 
bioRxiv preprint doi: https://doi.org/10.1101/2021.12.13.472353; this version posted December 13, 2021. The copyright holder for this preprint (which was not certified by peer review) is the author/funder, who has granted bioRxiv a license to display the preprint in perpetuity. It is made available under aCC-BY 4.0 International license.

dries in coastal locations in the spring and therefore was not sampled for analysis. The exact coordinates registered for each sampling location as well as the temperatures are available in Supplementary Table 1.

The water samples were cultured $(\mathrm{V}=1 \mathrm{ml})$ using sterile rakes on Mac Conkey and Mannitol Salt agar selective of Gram-negative bacteria and Staphylococcus spp. respectively, with and without antibiotics. For Gram-negative bacteria, we used ceftriaxone (2 $\mathrm{mg} / \mathrm{L})$, cefepime $(4 \mathrm{mg} / \mathrm{L})$ or ertapenem $(0.5 \mathrm{mg} / \mathrm{L})$. For Staphylococcus aureus, we used oxacillin $(4 \mathrm{mg} / \mathrm{L})$. All media were incubated at $37{ }^{\circ} \mathrm{C}$ for 48 hours. For Gram-negative bacteria, species identification was performed with API ${ }^{\circledast} 20$ NE (for Pseudomonas) or $\mathrm{API}^{\circledR} 20 \mathrm{E}$ (for Enterobacterales) galleries (Biomérieux). For S. aureus, we used three phenotypic tests: catalase, DNAse, and coagulase.

The susceptibility testing was performed on Muller-Hinton agar according to the European Committee on Antimicrobial Susceptibility Testing (EUCAST) v8 guidelines. Antibiotic Bio-Rad ${ }^{\circledR}$ discs used were: amoxcicillin-clavulanic acid $(20 \mu \mathrm{g}-10 \mu \mathrm{g})$,

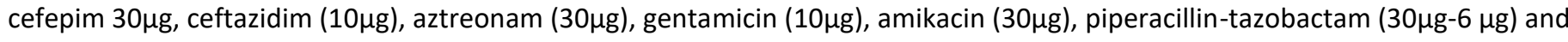
imipenem $(10 \mu \mathrm{g})$ for Gram-negative bacteria, and fusidic acid $(10 \mu \mathrm{g})$, cefoxitin $(30 \mu \mathrm{g})$, trimethoprim-sulfamethoxazole (1.25$23.75 \mu \mathrm{g})$, gentamicin $(10 \mu \mathrm{g})$, and ciprofloxacin $(5 \mu \mathrm{g})$ for $S$. aureus.

For molecular analysis, the three water samples per river were filtered (total volume of water filtered $=180 \mathrm{ml}$ ), using a filtration ramp (Sartorius, Göttingen, Germany), on a sterile $47 \mathrm{~mm}$ diameter filter with a pore size of $0.45 \mu \mathrm{m}$ (Sartorius, Göttingen, Germany). Microorganisms were recovered from filters and subject to DNA extraction for downstream analysis, using the DNeasy PowerWater ${ }^{\circledR}$ (Qiagen) adapted to water samples. All DNA samples were diluted or concentrated to a final concentration of 10 $\mathrm{ng} / \mu \mathrm{l}$ for downstream qPCR and $16 \mathrm{~S}$ rRNA analysis.

The Litani and Ibrahim rivers estuaries were excluded from the analysis as the respective water samples contained insufficient biomass even after an additional $2 \mathrm{~L}$ water volume sampling and DNA extraction.

We targeted 71 ARGs, 6 heavy metal resistance genes and 3 genes encoding resistance to quaternary ammonium compounds, 9 MGEs (transposases ISSW1, ISS1n, IS6100, IS613, IS6 group, Tn3, ISCEc9, tp614), and integron integrase genes (int/1, int/2, and int/3) ${ }^{10}$. The list of all the primers is published ${ }^{10}$. The $16 \mathrm{~S}$ rRNA encoding genes were targeted to allow normalizing the abundance of individual resistance genes.

The targeted genes are grouped according to their function ${ }^{10}$ with, in addition, the added environmental resistance marker: incP1 57.

High throughput real-time PCR was performed using the Biomark microfluidic system from Fluidigm in which every sample-gene

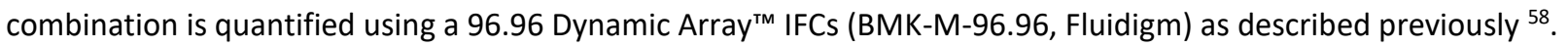

A mean normalized abundance for each ARGs' family and each estuary in spring and winter was calculated by dividing the cumulated abundance by the number of ARGs constituting the ARG family. The mean abundance of the ARGs families was then compared between spring and winter to assess a possible variation between the seasons. The estuaries where a significant variation was observed are listed in Supplementary Table 2. 


\section{Conclusions}

To date, this is the first study to provide an accurate assessment and comparison of the resistome in ten estuaries on the Lebanese coast. A combined approach using culture-based techniques and high throughput qPCR for the detection of ARBs and ARGs enabled identifying hotspots for antimicrobial resistance in the estuaries. This study highlighted the need to implement regular antibiotic resistance surveillance and improvement of waste management, in addition to the enforcement of regulations and guidelines stringency for sewage sludge or wastewater reuse as per the new EU 2020/741 legislation of the european parliament and of the council of 25 May 2020.

Supplementary Materials: Table 1: The exact coordinates of the sampling locations and the temperature recorded at the time of sampling, Table 2: Significant variations $(p<0.05)$ of ARGs families in the rivers between spring and winter.

Author Contributions: W.H. designed the study, W.H. performed experiments, W.H., and E.B. performed data analysis, W.H., wrote the original draft, E.B. and M-C.P writing-review and editing with contribution of all other co-authors.

Funding: This research was supported by The National Council for Scientific Research Lebanon CNRS-L, the Inserm and French Ministry of research, and the Research Council of the Saint Joseph University of Beirut.

Competing interests: The authors declare no conflict of interest. The funders had no role in the design of the study; in the collection, analyses, or interpretation of data; in the writing of the manuscript, or in the decision to publish the results.

\section{References}

1. Collignon, P., Beggs, J. J., Walsh, T. R., Gandra, S. \& Laxminarayan, R. Anthropological and socioeconomic factors contributing to global antimicrobial resistance: a univariate and multivariable analysis. Lancet Planet. Heal. 2, e398-e405 (2018).

2. Pieri, A. et al. Country income is only one of the tiles: The global journey of antimicrobial resistance among humans, animals, and environment. Antibiotics 9, 473 (2020).

3. Iskandar, K. et al. Drivers of antibiotic resistance transmission in low-and middle-income countries from a "one health" perspective-a review. Antibiotics 9, 372 (2020).

4. Kumar, S. B., Arnipalli, S. R. \& Ziouzenkova, O. Antibiotics in Food Chain: The Consequences for Antibiotic Resistance. 
Antibiotics 9, 688 (2020).

5. Goulas, A. et al. How effective are strategies to control the dissemination of antibiotic resistance in the environment? A systematic review. Environ. Evid. 9, 1-32 (2020).

6. Hernando-Amado, S., Coque, T. M., Baquero, F. \& Martínez, J. L. Defining and combating antibiotic resistance from One Health and Global Health perspectives. Nat. Microbiol. 4, 1432-1442 (2019).

7. Chatterjee, A. et al. Quantifying drivers of antibiotic resistance in humans: a systematic review. Lancet Infect. Dis. 18, e368-e378 (2018)

8. Dickinson, A. W. et al. Heavy metal pollution and co-selection for antibiotic resistance: A microbial paleontology approach. Environ. Int. 132, 105117 (2019).

9. Xiang, Q. et al. Spatial and temporal distribution of antibiotic resistomes in a peri-urban area is associated significantly with anthropogenic activities. Environ. Pollut. 235, 525-533 (2018).

10. Buelow, E. et al. Hospital discharges in urban sanitation systems: Long-term monitoring of wastewater resistome and microbiota in relationship to their eco-exposome. Water Res. X 100045 (2020) doi:10.1016/j.wroa.2020.100045.

11. Pazda, M., Kumirska, J., Stepnowski, P. \& Mulkiewicz, E. Antibiotic resistance genes identified in wastewater treatment plant systems-A review. Sci. Total Environ. 697, 134023 (2019).

12. Aubertheau, E. et al. Impact of wastewater treatment plant discharge on the contamination of river biofilms by pharmaceuticals and antibiotic resistance. Sci. Total Environ. 579, 1387-1398 (2017).

13. Pärnänen, K. M. M. et al. Antibiotic resistance in European wastewater treatment plants mirrors the pattern of clinical antibiotic resistance prevalence. Sci. Adv. 5, eaau9124 (2019).

14. Buelow, E., Ploy, M.-C. \& Dagot, C. Role of pollution on the selection of antibiotic resistance and bacterial pathogens in the environment. Curr. Opin. Microbiol. 64, 117-124 (2021).

15. Dandachi, I., Chaddad, A., Hanna, J., Matta, J. \& Daoud, Z. Understanding the epidemiology of multi-drug resistant gramnegative bacilli in the Middle East using a one health approach. Front. Microbiol. 10, 1941 (2019). 
16. Jammoul, A. \& El Darra, N. Evaluation of antibiotics residues in chicken meat samples in Lebanon. Antibiotics 8, 69 (2019).

17. Vaz-Moreira, I., Ferreira, C., Nunes, O. C. \& Manaia, C. M. Sources of Antibiotic Resistance: Zoonotic, Human, Environment. Antibiot. Drug Resist. 211-238 (2019).

18. Lundborg, C. S. \& Tamhankar, A. J. Antibiotic residues in the environment of South East Asia. Bmj 358, j2440 (2017).

19. Triggiano, F. et al. The Role of Urban Wastewater in the Environmental Transmission of Antimicrobial Resistance: The Current Situation in Italy (2010-2019). Microorganisms 8, 1567 (2020).

20. Cacace, D. et al. Antibiotic resistance genes in treated wastewater and in the receiving water bodies: A pan-European survey of urban settings. Water Res. 162, 320-330 (2019).

21. Huijbers, P. M. C., Flach, C.-F. \& Larsson, D. G. J. A conceptual framework for the environmental surveillance of antibiotics and antibiotic resistance. Environ. Int. 130, 104880 (2019).

22. Karkman, A., Pärnänen, K. \& Larsson, D. G. J. Fecal pollution can explain antibiotic resistance gene abundances in anthropogenically impacted environments. Nat. Commun. 10, 80 (2019).

23. An, X.-L. et al. High-throughput diagnosis of human pathogens and fecal contamination in marine recreational water. Environ. Res. 190, 109982 (2020).

24. Guo, X., Feng, C., Gu, E., Tian, C. \& Shen, Z. Spatial distribution, source apportionment and risk assessment of antibiotics in the surface water and sediments of the Yangtze Estuary. Sci. Total Environ. 671, 548-557 (2019).

25. Zhang, Y., Niu, Z., Zhang, Y. \& Zhang, K. Occurrence of intracellular and extracellular antibiotic resistance genes in coastal areas of Bohai Bay (China) and the factors affecting them. Environ. Pollut. 236, 126-136 (2018).

26. Guo, X. et al. Seasonal and spatial distribution of antibiotic resistance genes in the sediments along the Yangtze Estuary, China. Environ. Pollut. 242, 576-584 (2018).

27. Wu, D., Su, Y., Xi, H., Chen, X. \& Xie, B. Urban and agriculturally influenced water contribute differently to the spread of antibiotic resistance genes in a mega-city river network. Water Res. 158, 11-21 (2019). 
28. Wang, S. et al. Selectively enrichment of antibiotics and ARGs by microplastics in river, estuary and marine waters. Sci. Total Environ. 708, 134594 (2020).

29. Kazour, M., Jemaa, S., Issa, C., Khalaf, G. \& Amara, R. Microplastics pollution along the Lebanese coast (Eastern Mediterranean Basin): Occurrence in surface water, sediments and biota samples. Sci. Total Environ. 696, 133933 (2019).

30. Dagher, L. A., Hassan, J., Kharroubi, S., Jaafar, H. \& Kassem, I. I. Nationwide Assessment of Water Quality in Rivers across Lebanon by Quantifying Fecal Indicators Densities and Profiling Antibiotic Resistance of Escherichia coli. Antibiotics 10, 883 (2021).

31. Andraos, C. \& Najem, W. Multi-model Approach for Reducing Uncertainties in Rainfall-Runoff Models. in Advances in Hydroinformatics 545-557 (Springer, 2020).

32. Baalbaki, R. et al. Comparison of atmospheric polycyclic aromatic hydrocarbon levels in three urban areas in Lebanon. Atmos. Environ. 179, 260-267 (2018).

33. Maher Salman, Motasem Abukhalaf, A. D. L. Assessment of treated wastewater for agriculture in lebanon. FAO (2016).

34. Merhabi, F. et al. Occurrence, Distribution, and Ecological Risk Assessment of Emerging and Legacy Contaminants in the Kadicha River in Lebanon. (2021).

35. Mikhayel, M., Leclercq, S. O., Sarkis, D. K. \& Doublet, B. Occurrence of the Colistin resistance gene mcr-1 and additional antibiotic resistance genes in ESBL/AmpC-producing Escherichia coli from poultry in Lebanon: A nationwide survey. Microbiol. Spectr. 9, e00025-21 (2021).

36. Meade, E., Savage, M. \& Garvey, M. Effective Antimicrobial Solutions for Eradicating Multi-Resistant and $\beta$-LactamaseProducing Nosocomial Gram-Negative Pathogens. Antibiotics 10, 1283 (2021).

37. Luo, Q., Wang, Y. \& Xiao, Y. Prevalence and transmission of mobilized colistin resistance (mcr) gene in bacteria common to animals and humans. Biosaf. Heal. 2, 71-78 (2020).

38. Jaafar, H., Ahmad, F., Holtmeier, L. \& King-Okumu, C. Refugees, water balance, and water stress: Lessons learned from Lebanon. Ambio 49, 1179-1193 (2020). 
39. Lebanon water quality survey. WHO/UNICEF (2019).

40. Yassin, N. 101Facts \& Figures.

41. Fayad, A. Evaluation of the snow water resources in mount lebanon using observations and modelling. (2017).

42. Vourli, S. et al. Characterization of In111, a class 1 integron that carries the extended-spectrum $\beta$-lactamase gene bla IBC- 1. FEMS Microbiol. Lett. 225, 149-153 (2003).

43. Alikhani, M. Y. et al. Antimicrobial resistance patterns and prevalence of blaPER-1 and blaVEB-1 genes among ESBLproducing Pseudomonas aeruginosa isolates in West of Iran. Jundishapur J. Microbiol. 7, (2014).

44. Weldhagen, G. F., Poirel, L. \& Nordmann, P. Ambler class A extended-spectrum $\beta$-lactamases in Pseudomonas aeruginosa: novel developments and clinical impact. Antimicrob. Agents Chemother. 47, 2385-2392 (2003).

45. Vahaboglu, H. et al. Widespread detection of PER-1-type extended-spectrum beta-lactamases among nosocomial Acinetobacter and Pseudomonas aeruginosa isolates in Turkey: a nationwide multicenter study. Antimicrob. Agents Chemother. 41, 2265-2269 (1997).

46. Bush, K. \& Bradford, P. A. Epidemiology of $\beta$-lactamase-producing pathogens. Clin. Microbiol. Rev. 33, e00047-19 (2020).

47. Morris, S. \& Cerceo, E. Trends, epidemiology, and management of multi-drug resistant gram-negative bacterial infections in the hospitalized setting. Antibiotics 9, 196 (2020).

48. Ho, J. Y. et al. Multidrug-resistant bacteria and microbial communities in a river estuary with fragmented suburban waste management. J. Hazard. Mater. 405, 124687 (2021).

49. Moritz, C. F., Snyder, R. E., Riley, L. W., Immke, D. W. \& Greenfield, B. K. Antimicrobial Drug-Resistant Gram-Negative Saprophytic Bacteria Isolated from Ambient, Near-Shore Sediments of an Urbanized Estuary: Absence of $\beta$-Lactamase Drug-Resistance Genes. Antibiotics 9, 400 (2020).

50. Silva, V., Caniça, M., Capelo, J. L., Igrejas, G. \& Poeta, P. Diversity and genetic lineages of environmental staphylococci: a surface water overview. FEMS Microbiol. Ecol. 96, fiaa191 (2020).

51. Tsai, H.-C. et al. Multidrug-resistance in methicillin-resistant Staphylococcus aureus (MRSA) isolated from a subtropical 
bioRxiv preprint doi: https://doi org/10.1101/2021.1213.472353; this version posted December 13,2021 . The copyright holder for this preprint (which was not certified by peer review) is the author/funder, who has granted bioRxiv a license to display the preprint in perpetuity. It is made available under aCC-BY 4.0 International license.

river contaminated by nearby livestock industries. Ecotoxicol. Environ. Saf. 200, 110724 (2020).

52. Ramessar, K. \& Olaniran, A. O. Antibiogram and molecular characterization of methicillin-resistant Staphylococcus aureus recovered from treated wastewater effluent and receiving surface water in Durban, South Africa. World J. Microbiol. Biotechnol. 35, 1-11 (2019).

53. Ibekwe, A. M. \& Murinda, S. E. Linking microbial community composition in treated wastewater with water quality in distribution systems and subsequent health effects. Microorganisms 7, 660 (2019).

54. Hammer-Dedet, F., Jumas-Bilak, E. \& Licznar-Fajardo, P. The Hydric Environment: A Hub for Clinically Relevant Carbapenemase Encoding Genes. Antibiotics 9, 699 (2020).

55. Singh, R., Singh, A. P., Kumar, S., Giri, B. S. \& Kim, K.-H. Antibiotic resistance in major rivers in the world: a systematic review on occurrence, emergence, and management strategies. J. Clean. Prod. (2019).

56. Shaban, A. Water Resources of Lebanon. (2020).

57. González-Plaza, J. J. et al. Antibiotic-manufacturing sites are hot-spots for the release and spread of antibiotic resistance genes and mobile genetic elements in receiving aquatic environments. Environ. Int. 130, 104735 (2019).

58. Buelow, E. et al. Limited influence of hospital wastewater on the microbiome and resistome of wastewater in a community sewerage system. FEMS Microbiol. Ecol. 94, fiy087 (2018). 


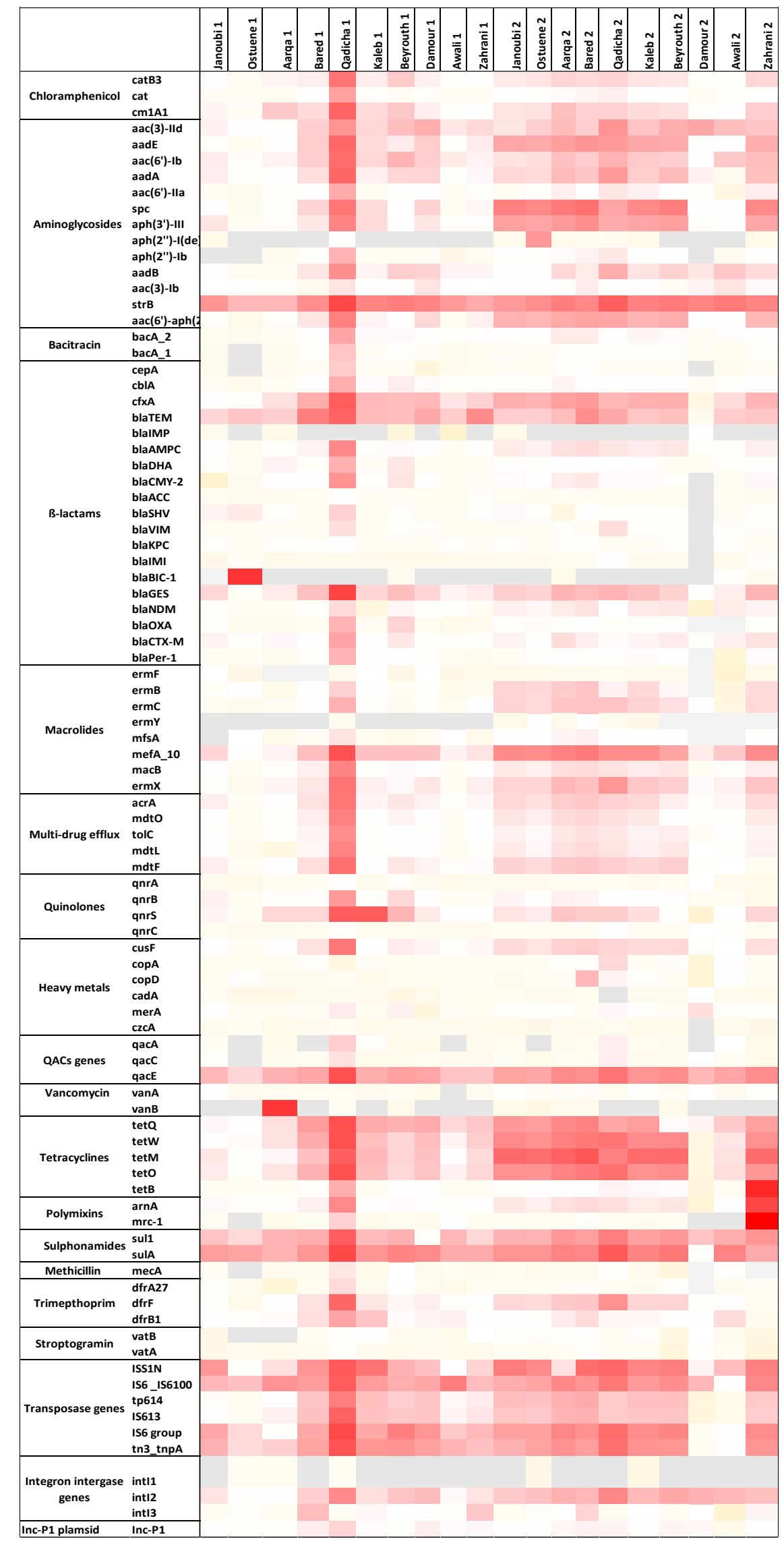

Figure 1. Heat map depicting the normalized abundances to the 16S rRNA gene of each targeted gene in spring (1) and in winter (2) in the 10 estuarine Lebanese rivers samples. Red: highest abundance, light yellow: lowest abundance, white medium, and grey: not detected 


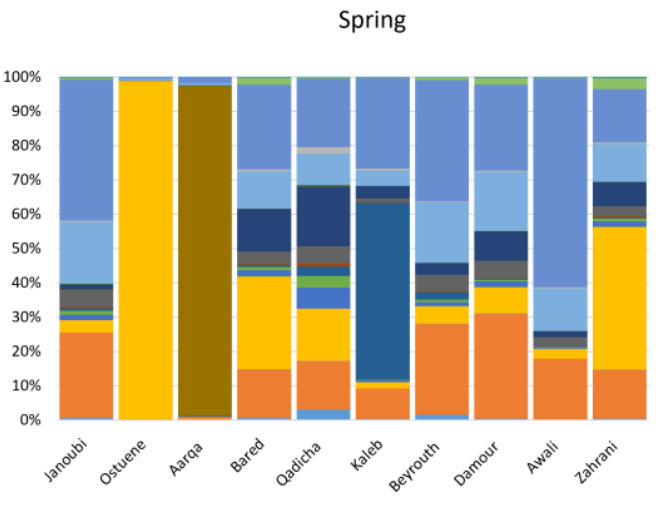

(a)

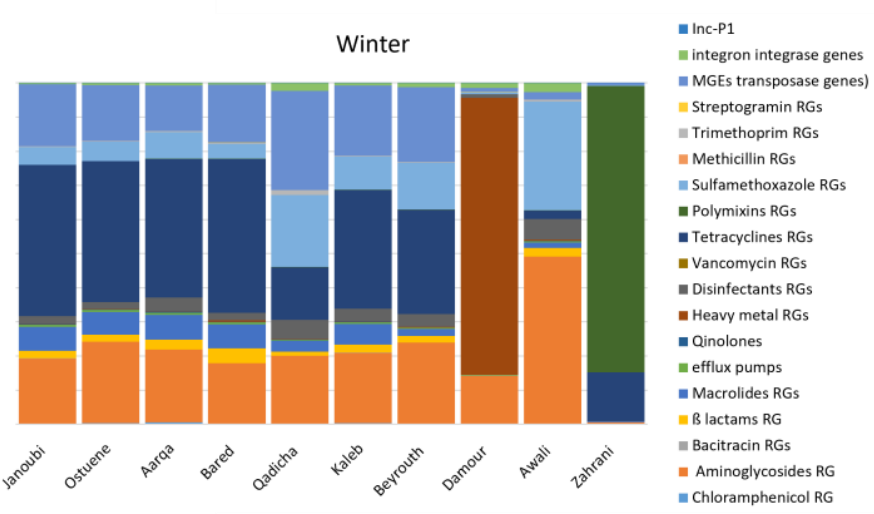

(b)

Figure 2. Proportional abundances of the variation of the ARGs families per river in (a) spring and in (b) winter in 10 estuarine Lebanese rivers samples 

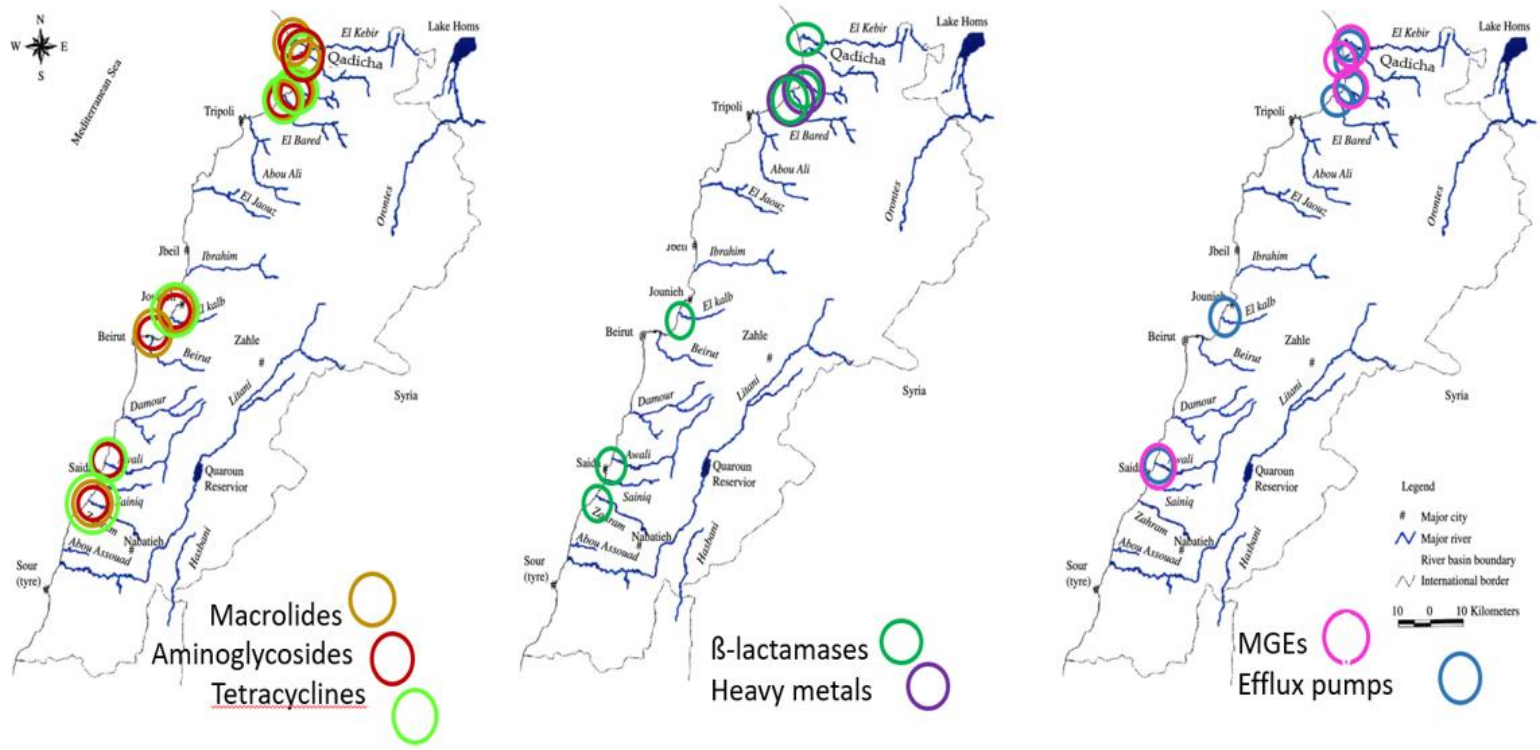

Figure 3. Graphical representation showing the estuaries where an increase in the mean normalized abundances of the ARGs families and MGEs from spring to winter was significant $(p<0.05)$. 


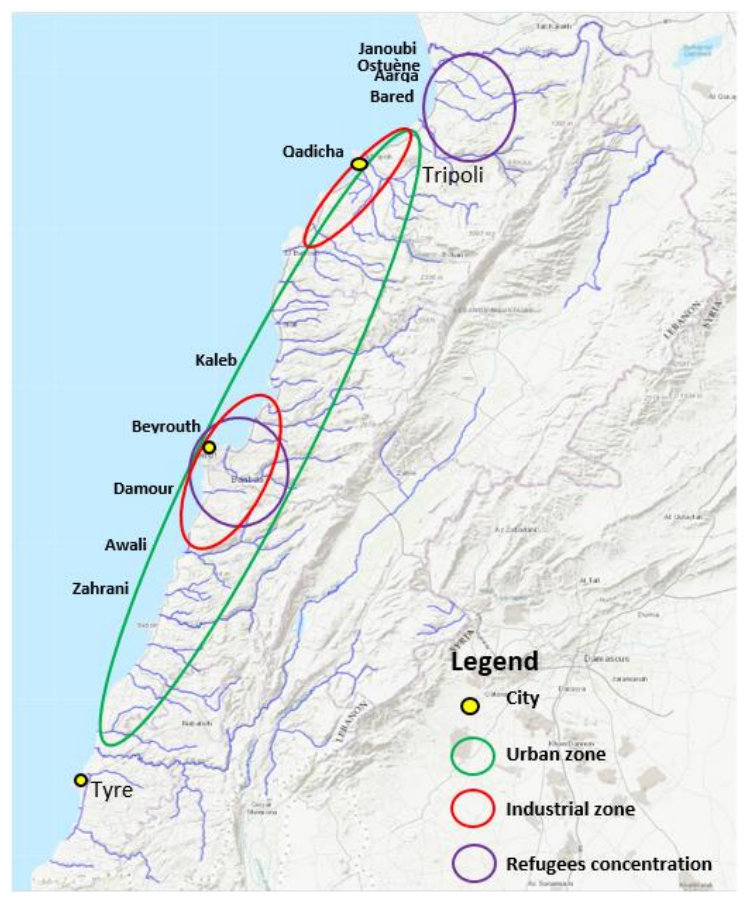

Figure 4. High anthropogenic impact locations. A map from “Rivers, Lebanon, 2012. https://maps.princeton.edu/catalog/stanfordwn533df2039" representing the Lebanese rivers, modified to show locations on the Lebanese cost of the biggest industrial zones (Beirut and Tripoli), the highest urbanized area and location of refugees according to the UNHCR, UN-habitat 2014 and the UNRWA 2021 organizations. 


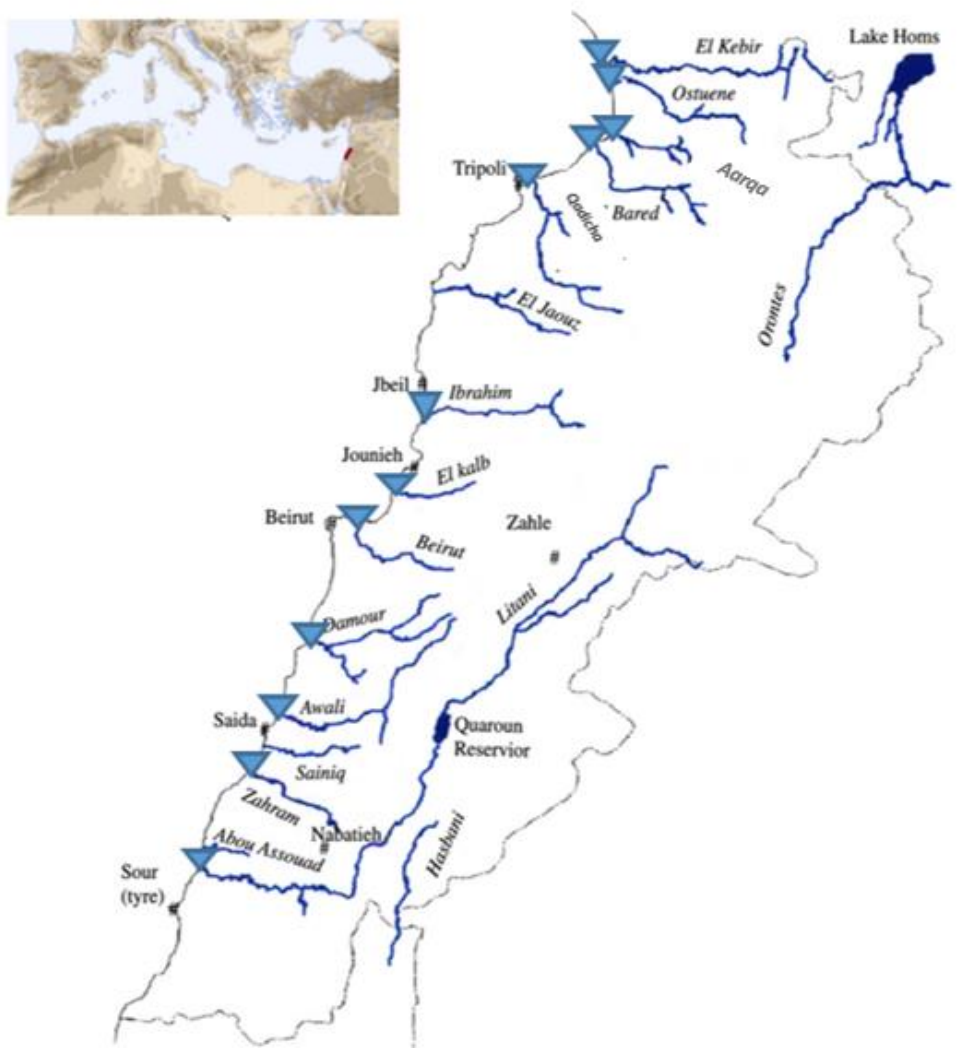

Figure 5. Sampling sites are represented as blue triangles on the map of the Lebanese rivers. Figure adapted from Houri \& El Jeblawi, 2007 
bioRxiv preprint doi: https://doi org/10.1101/2021.1213472353; this version posted December 13,2021 . The copyright holder for this

preprint (which was not certified by peer review) is the author/funder, who has granted bioRxiv a license to display the preprint in perpetuity. It is made available under aCC-BY 4.0 International license.

Table 1. Gram-negative bacterial species isolated in the rivers' estuaries

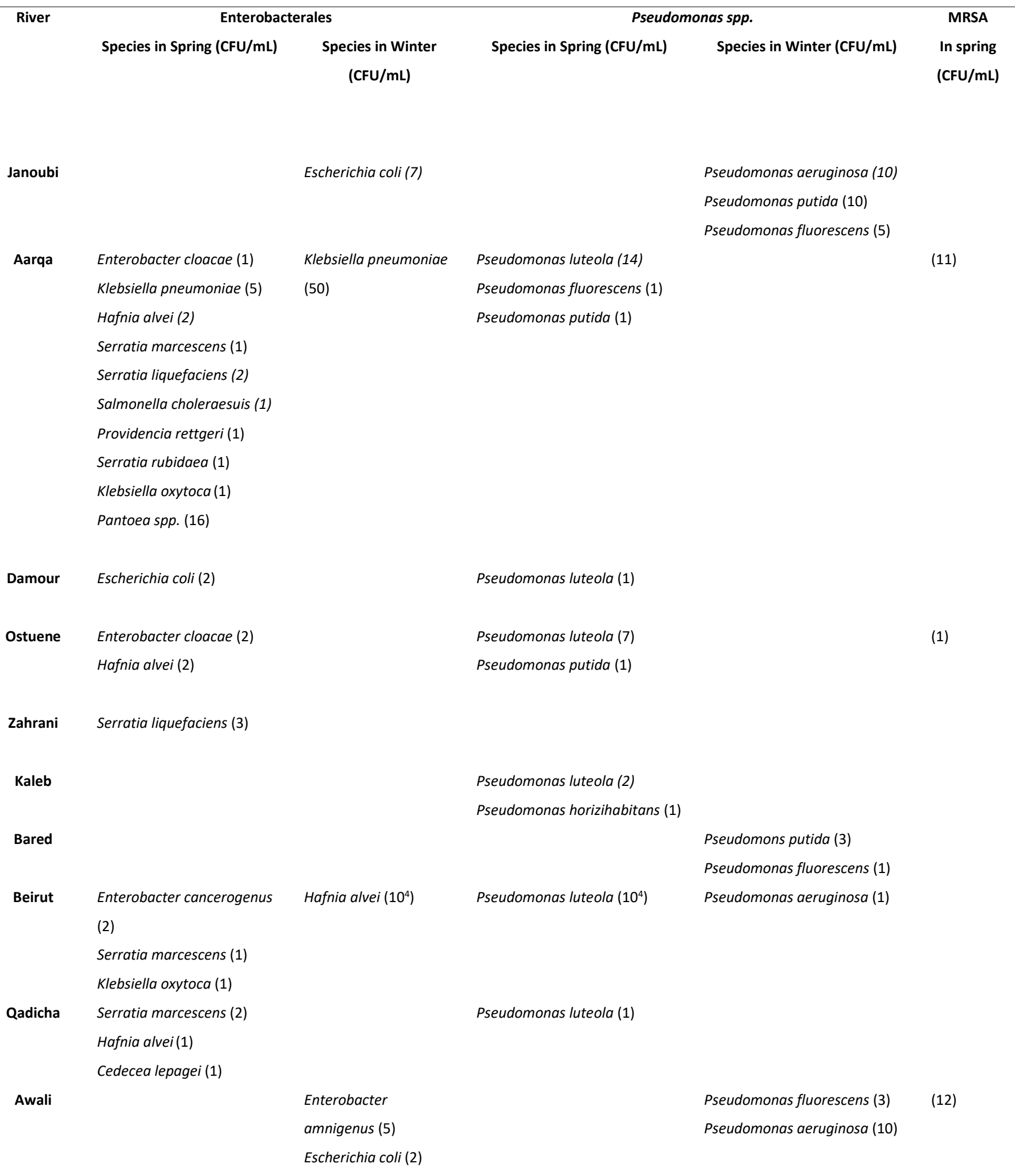


Table 2. Resistance of the tested Enterobacterales and Pseudomonas species: numbers indicate the number of strains resistant out of the strains tested (\%).

\begin{tabular}{ccccc}
\hline & \multicolumn{2}{c}{ Enterobacterales } & \multicolumn{2}{c}{ Pseudomonas } \\
\hline & Spring & Winter & Spring & Winter \\
\hline Cefepime & $16 / 27$ & $6 / 6$ & $6 / 31$ & $5 / 8$ \\
& $(59 \%)$ & $(100 \%)$ & $(19 \%)$ & $(63 \%)$ \\
Imipenem & $2 / 27$ & $0 / 6$ & $3 / 31$ & $0 / 8$ \\
& $(7 \%)$ & $(0)$ & $(10 \%)$ & $(0)$ \\
Ceftazidime & $17 / 27$ & $5 / 6$ & $6 / 31$ & $5 / 8$ \\
& $(63 \%)$ & $(83 \%)$ & $(19 \%)$ & $(63 \%)$ \\
Piperacillin- & $6 / 27$ & $4 / 6$ & $3 / 31$ & $4 / 8$ \\
tazobactam & $(22 \%)$ & $(67 \%)$ & $(10 \%)$ & $(50 \%)$ \\
Gentamicin & $5 / 27$ & 67 & $0 / 31$ & $1 / 8$ \\
& $(19 \%)$ & $(17 \%)$ & $(0)$ & $(13 \%)$ \\
Amikacin & $2 / 27$ & $1 / 6$ & $2 / 31$ & $1 / 8$ \\
& $(7 \%)$ & $(17 \%)$ & $(6 \%)$ & $(13 \%)$ \\
Aztreonam & $21 / 27$ & $6 / 6$ & $27 / 31$ & $8 / 8$ \\
& $(78 \%)$ & $(100 \%)$ & $(87 \%)$ & $(100 \%)$ \\
\hline
\end{tabular}


bioRxiv preprint doi: https://doi.org/10.1101/2021.12.13.472353; this version posted December 13, 2021. The copyright holder for this preprint (which was not certified by peer review) is the author/funder, who has granted bioRxiv a license to display the preprint in perpetuity. It is made available under aCC-BY 4.0 International license. 